\begin{tabular}{ll}
\hline \hline MINING AND METALLURGY INSTITUTE BOR & ISSN: 2334-8836 (Štampano izdanje) \\
UDK: 622 & ISSN: 2406-1395 (Online) \\
\hline \hline
\end{tabular}

Slavica Miletic ${ }^{*}$, Dejan Bogdanovic ${ }^{* *}$, Jane Paunkovic ${ }^{* * * *}$

\title{
SELECTION OF THE OPTIMAL MODEL OF INTEGRATED SUSTAINABLE MANAGEMENT SYSTEM IN THE MINING COMPANIES
}

\begin{abstract}
The multi-criteria analysis for the selection of the optimal model of integrated management system was conducted in this paper in order to improve the performance of mining companies. Integrated management system is the process of integrating of different management systems in a contemporary business as a requirement for each company in order to survive in the market. Modern companies that have implemented integrated management system work better, have arranged processes, improve its structure and culture for the management practice, and have continual improvements of all processes.

Mining companies are in a very difficult position in Serbia. Their business is specific because it is characterized by a high complexity, obsolete and complex organizational structure, inadequate management practices, everyday functioning and many other problems. In that context, authors are proposing four models of integrated management systems that could be applicable in mining companies in order to improve their performance. Also, the appropriate criteria for the selection of the optimal model are defined. AHP method is applied for the selection and ranking of the models of integrated management system. The obtained results give an optimal model of integrated management system that is applicable with the best results in terms of performance improvement and sustainability of mining companies in Serbia.
\end{abstract}

Keywords: Integrated system management, Mining, AHP method

\section{INTRODUCTION}

Implementation of the integrated management system (IMS), composed of different management systems, has received a lot of attention in recent years. The integrated management system is defined as a comprehensive management tool that links all elements of the business system in a unique and comprehensive system of processes management in the organization, in order to meet the demands of stakeholders [1]. Today, there are more models of implementation of the IMS, and they were created based on the specific requirements of stakeholders and the companies themselves. Companies that have implemented the optimal model of IMS, have significant benefit such as: continuous improvement of processes, obtaining a unique quality of products and services,

\footnotetext{
* Mining and Metallurgy Institute Bor

** University of Belgrade,Technical Faculty in Bor

${ }^{* * * *}$ Megatrend University, Faculty for Managementt Zajecar

**** This work in the results of the Project TR 34023 "Development the Technological Processes of Treatment the Non-standard Copper Concetrates to the Aim of Optimization the Emission of Polluting Materials and TR 37001 "The Effect of Mine Waste from RTB Bor and Pollution the Waterflows with a Proposal of Measures and Procedures for Reductid the Harmful Effect on the Environment", funded by the Ministry of Education, Science and Technological Development of the Republic of Serbia
} 
improving the organizational culture, the greater degree of satisfaction of stakeholders and others. The additional value of integrated management systems is that they are in accordance with a concept of sustainable development that institutes a balance between technological development necessary for economic prosperity and survival of the environment and society as a whole [2]. The key issue for the management of the mining companies is to align management system with different standards, and consequently how to make internal alignment of partial management systems in the company. Additionally, it is often difficult to take the advantage of already implemented system, and to choose the optimal model of IMS. Because of its specificity, the mining companies must first identify the requirements of stakeholders and subsequently select an optimal model of implementation of the IMS. Since all elements of standardized management systems are mutually compatible, it enables all partial management systems to form a single integrated management system (IMS) in which there are strong interconnections between the individual elements of the system [3]. Accordingly, the integrated management system is established through the commitment of the organization's management to implement the requirements of standards, raising awareness about the importance of planning processes and continuous improvement of business processes, thus creating the conditions for success.

The commercial success of mining companies precedes proper selection of the optimal model of IMS that will bring significant improvements in time, such as higher level of satisfaction of all stakeholders from the owner, manager, and to the end user of products and services, i.e. consumer or customer.

\section{MODELS OF INTEGRATED MANAGEMENT SYSTEMS}

There are a numerous models of IMS that have been successfully applied in commercial companies. Basic models of IMS originally were the quality management system (ISO 9001) and the system of environmental management (ISO 14001), which later became integrated into the system management of health and safety (OHSAS 18001). Further development led to the creation of the new models of IMS that take into account the type of activity of certain companies, as well as all interested parties and stakeholders. The system that in itself integrates the requirements of several standards primarily aims to satisfy the demands of many stakeholders, because it is often the case that different stakeholders require different management systems, i.e. management systems compliant only with certain standards or [4].

This paper explores the practices of sustainable mining companies implementation the optimal model of IMS, analyzed by Analytical Hierarchy Process (AHP method). AHP is one of the multi-criteria decisionmaking methods for the selection of the best solution among several alternatives [5]. The advantage of this method is that it can simultaneously consider both financial and nonfinancial factors in the process of selecting the optimal model of IMS [6]. There are four alternatives that are discussed here (four models of IMS) which have been successfully applied in developed countries. These models are based on the fundamental principles and the process approach in the development of the integration process of management.

\subsection{Wilkinson - Dale's model (alternative A1)}

The integrated systems in Wilkinson Dale's model consists of: the system of quality management (QMS), the system of environmental management (EMS) and the system of occupational health and safety (OHSAS) [7] - Figure 1. Differentiation and specificity of this model is that it includes an integrated culture and elements of TQM 
model (Total Quality Management). Wilkinson - Dale's model of integration depends on the requirements and policies of any organization or interested party. Stakeholders may be managers (a successful business), employees themselves (wages, working conditions), suppliers (long term collaboration), customers (quality and price of a product), community (environment), owners (profits) and others.

This model can be implemented by any organization that takes the quality system, environmental protection system and the system of protection of health and safety at work as a priority in their business. Also, this model can be implemented by organizations that are involved in the activities of TQM works of continuous improvement.
Wilkinson and Dale model puts a great importance to sustainability culture in organizations that could lead to the creation of organizational culture which enhances the implementation of the integration system.

It is very important for the mining company that implements the IMS to select a model that takes into consideration a national culture, because it can improve the successful realization of this process. The importance of incorporation of national culture model is explained in a work of Geert Hofstede's [8]. Geert Hofsted is the most cited social science author - 123707 citations in Google Scholar [9]. Authors of this paper have considerable experience in research of organizational and national culture relations in Serbia [10, 11]).

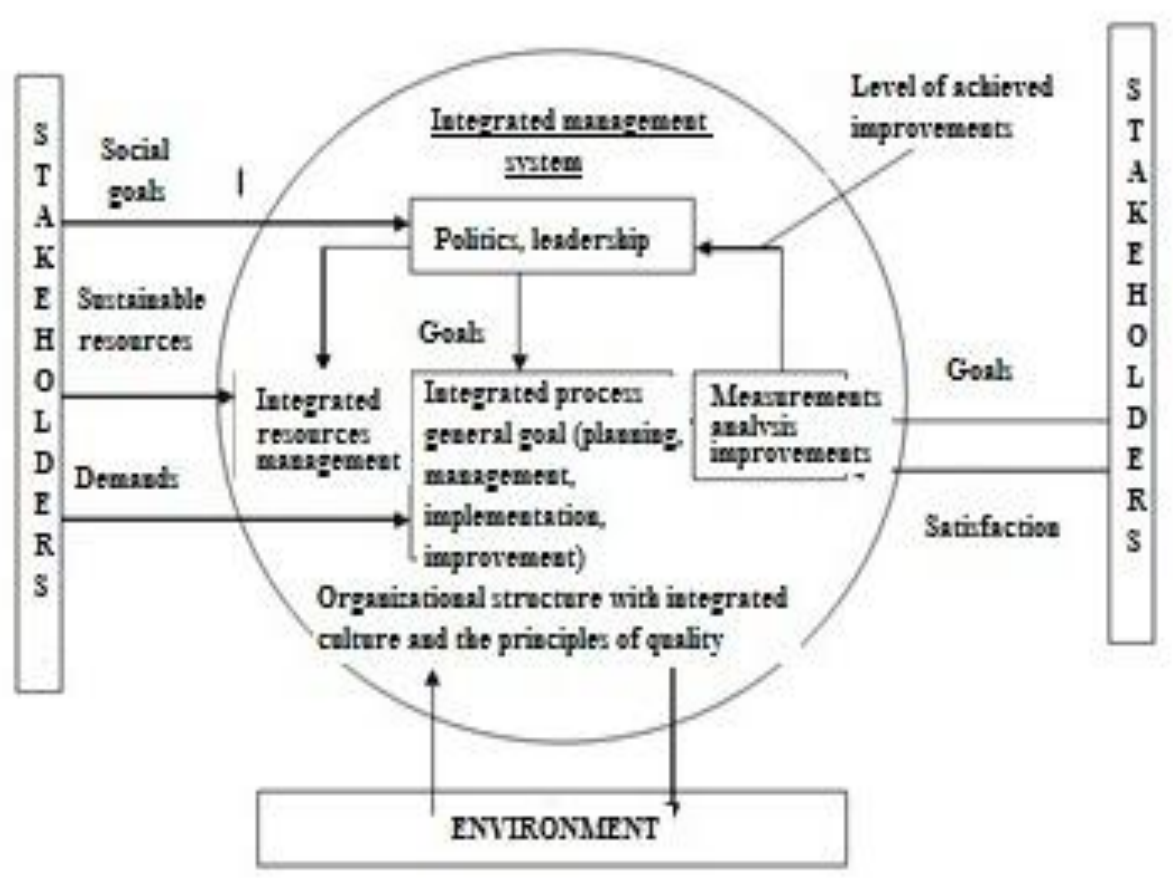

Figure 1 The extended Wilkinson - Dale's model of IMS [7] 


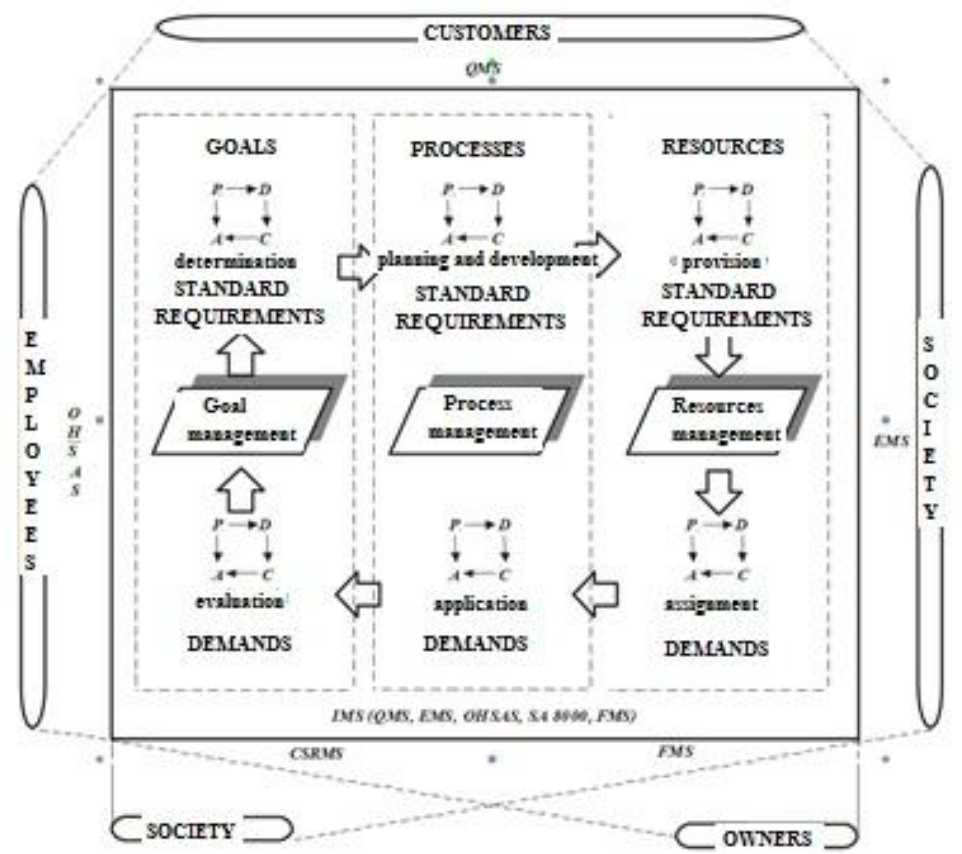

Figure 2 Karapetrovic's model [13]

\subsection{Karapetrovic's model (alternative A2)}

This model includes integration of five systems - QMS, EMS, OHSAS, the corporate social responsibility management system (CSRMS) and the financial management system (FMS). This means that the model includes the requirements of the standards and requirements of stakeholders. The model is based on a systematic approach and the PDCA cycle - plan, do, check and act - improve.

The focus of Karapetrovic's model, except for customers, is directed to the satisfaction of stakeholders of the community (environment), staff reductions (injury), management (reducing business risk), as well as other stakeholders $[12,13]$. The implementation of management systems is done through management to objectives, process management and resource management -
Figure 2. Karapetrovic's model is compatible with the PDCA management system, because it considers all processes with a goal to their continual improvement and enhancements. These processes are: goals, planning and development processes, resourcing, scheduling, resource management, application in management processes and evaluation of management objectives.

This model is applicable to all industrial companies - manufacturing and service industries.

Characteristics of the company (type of activity, their specifics, size and demands of stakeholders) instigated development of the new standardized management system (MSS - Management Systems Standards) in order to meet their specific requirements and easier implementation of the IMS. 


\subsection{The process model (alternative A3)}

In this model, each process, sub-process and activity has inputs - the demands of stakeholders, and outputs - satisfaction of stakeholders - Figure 3. During production the measurements, analysis and improvements are carried out by management supervision.

The management systems that are based on essentially procedural approach of ISO 9000 can be identified through integration strategy [14].

Specifics of the process model are reflected through the application of process approach, and it integrates the $\mathrm{N}$ systems: QMS, EMS, OHSAS and Food Safety Management System (HACCP). These standards have similarities within their structure, so the integration of the standards can be made on the basis of identical and specific requirements that must be resolved in the management process. That is why the process approach represents a new management approach. The essence of the standards for management systems (ISO 9001, ISO 14001, OHSAS 18001 and ISO 22000) is precisely in the processes management.

The process model during its implementation requires knowledge about the organization, the requirements of stakeholders, defining management methodology, determining the necessary resources and the implementation of all procedures with continuous improvement and enhancement. During the implementation of the process model, person in charge, owner or manager of the process is responsible for the documentation, implementation requirements (products or services) and measurement of satisfaction of stakeholders. Also, employees and all participants in the process are responsible for the realization of the implementation of this process.

This model is highly represented in Serbia (in approximately $96 \%$ of all companies).

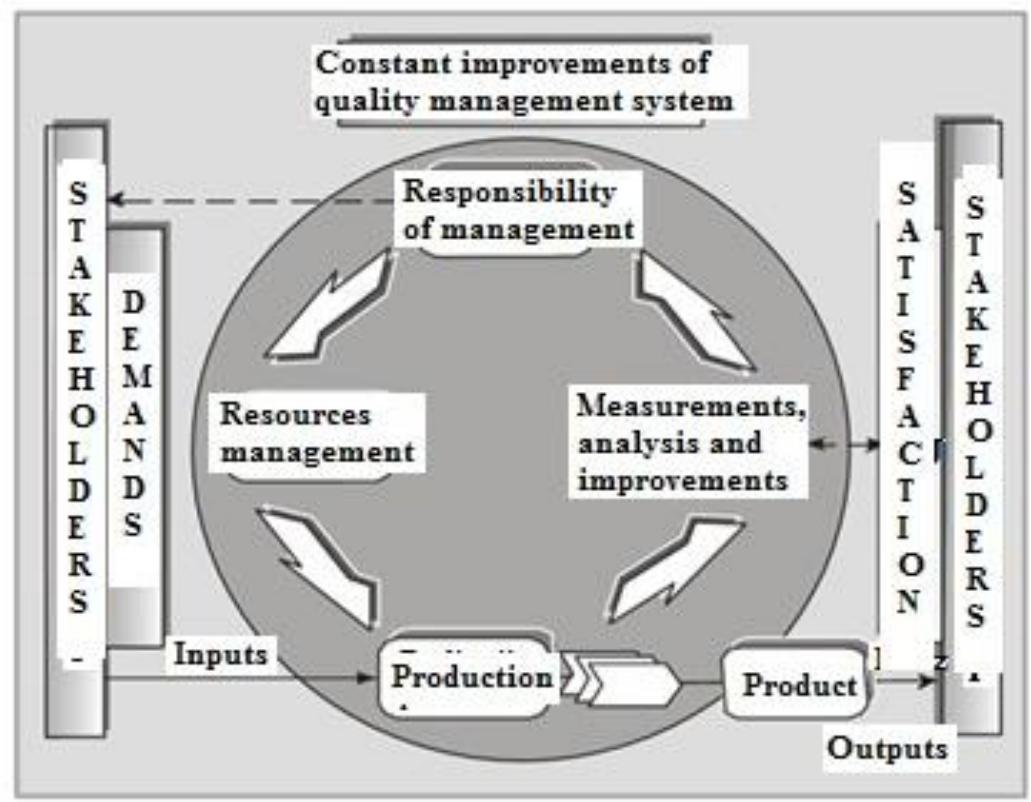

Figure 3 Model of quality management system based on processes [14] 


\subsection{EFQM excellence model (alternative A4)}

EFQM excellence model was created by the European Foundation for Quality Management in 1992 and promoted in 1999. The model is the basis for the European Quality Award for the following:

- large companies and

- small and medium companies
Unlike the others, this model is based on philosophy of Total Quality Management (TQM) and on two systems-integration (interoperability), such as quality management system and environmental management system (EFQM, 1998, EFQM, 2002) - Figure 4 .

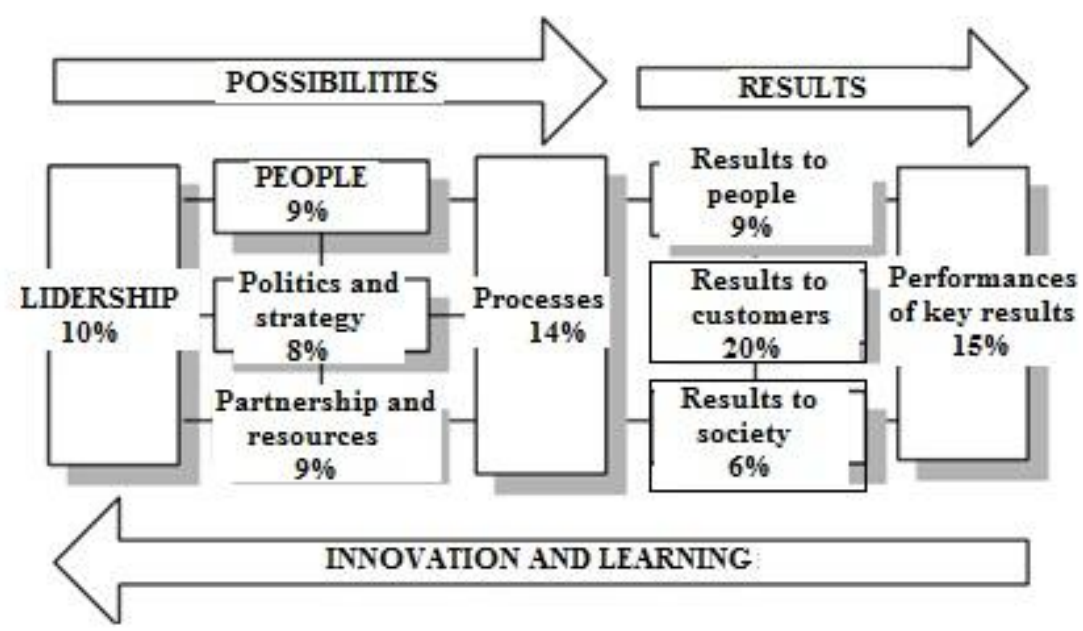

Figure 4 EFQM excellence model [15]

This model has nine criteria where five are related to opportunities that show what the company does, while others refer to results. The results show the extent to which the organization uses opportunities.

The EFQM excellence model is applicable in companies whose requirements are such that they can develop their own approaches to achieving excellence. Within this model, there are a few basic concepts that are required for its implementation, namely:

- orientation to results, where results show excellence that are satisfaction of stakeholders;
- focus on customers, where the excellence is creating a stable customer;

- leadership and consistency determination, where is the excellence in leadership with a persistent feature;

- process and facts management, where is the excellence management company on the basis of processes and facts;

- inclusion of employees and their development, where is the excellence in employees motivation to increase contributions;

- improvement, innovation and continuous education, where the excellence is in innovation to create the 
possibility for more sophisticated operations;

- development of partnership, where excellence is manifested through the development and maintenance of partnerships with the increasing value;

- social responsibility, where excellence is reflected in overcoming some minimum obligations in the company and where the company aims to more responsible understanding of the demands of society.

The criteria for achieving the business excellence are: leadership, people, policy and strategy, partnership and resources, processes, results to customers and society, and finally results that make the satisfaction of all stakeholders.

Common features of the EFQM model, the process model, Karapetrovic's model and Wilkinson - Dale's model are: systemic approach, continuous improvement, satisfying demands of all stakeholders, reducing the extensive documentation and that they are applicable in the all types of organizations including mining companies.

\section{DEFINING THE CRITERIA FOR SELECTION OF THE OPTIMAL MODEL OF IMS}

The criteria include the most important characteristics for the selection of the optimal model of implementation of the IMS in mining companies, namely:

The cost of implementation of the IMS (criterion C1) is a very important factor for the choice of an optimal model of IMS. The cost of implementation is determined for each proposed model of IMS in mining companies and influence is proportional to the obtained results.

The expected effects of the IMS (criterion C2) is a very important factor that has a major influence in selecting process of the optimal model of implementation of IMS. By implementation of optimal model of IMS, mining companies should make signi- ficant improvements, such as building a model of organizational culture aligned with national culture, better implementation of its policies and strategies, greater employee satisfaction, injuries reduction at work, constant improvement of resources (material, financial and human), continuous improvement of business processes, improvements of corporate governance, satisfied external and internal customers, a better relationship to society, improving environmental protection, operations according to all the rules and regulations, the ability of business to the global market, the advantage in participating in the tender, cost reduction, etc.

The time required for implementation of the IMS (criterion C3) is also a very important factor that significantly influences the choice of optimal method of IMS. For example, if the implementation takes longer period than expected, some of the interested party will not met the requirements, which implies that their dissatisfaction reflects on the others, so that all can led to bad reputation of mining company within the community. Some of these models of IMS demand a shorter implementation period which can be very important for mining companies.

The applicability of the model (criterion C4) is a criterion that indicates the degree of implementation possibilities of a particular model of IMS in mining companies. Some models are easier to implement and others more difficult. The aim is that mining companies choose the model that is not difficult to implement and that it will bring many long-term benefits to them. In addition, mining companies must take into account many factors, such as their own specificities, equipment condition, the structure of labor, management of the companies and others.

\section{AHP METHOD}

AHP is a quantitative technique that allows the structuring of complex decision problems with multiple criteria and provides 
an objective methodology for a wide range of decisions.

AHP is based on decomposition the complex decision problems in multi-dimensional hierarchical structure of objectives, criteria and alternatives. After that, impact assessment of criteria is done. Then comparison of the alternatives in relation to each criterion is made, and final ranking of alternatives is obtained.

Assessment of the relative impact of each criterion and comparison of alternatives in relation to the criteria is performed by matrix of comparison. These include: the formation of matrix of comparisons at each level of the hierarchy, starting from the second level down; calculation of weight coefficients for each element of the hierarchy and the assessment of the degree of consistency in order to check the consistency of the entire process.

According to that, a set of alternatives $\{\mathrm{A} 1, \mathrm{~A} 2, \ldots, \mathrm{An}\}$ is defined, as well as a set of criteria weight coefficients $\{w 1, w 2, \ldots, w n\}$.

Comparison of criteria and alternatives is made on the basis of the scale with scores from 1 to 9 - Table 1 .

Table 1 Scale of comparison of decision elements

\begin{tabular}{|l|l|}
\hline Dominance \\
\hline description & Value \\
\hline Equal & 1 \\
\hline Weak dominance & 3 \\
\hline Strong dominance & 5 \\
\hline Very strong dominance & 7 \\
\hline Absolutely dominance & 9 \\
\hline $2,4,6,8$ are intermediate values \\
\hline
\end{tabular}

The result of the comparison of criteria is the matrix that has the following form:

$$
W=\left[w_{i} / w_{j}\right]=\left[\begin{array}{cccc}
w_{1} / w_{l} & w_{1} / w_{2} & \ldots & w_{1} / w_{n} \\
w_{2} / w_{1} & w_{2} / w_{2} & \ldots & w_{2} / w_{n} \\
\ldots & \ldots & \ldots & \ldots \\
w_{n} / w_{1} & w_{n} / w_{2} & \ldots & w_{n} / w_{n}
\end{array}\right]
$$

After that, the comparison of pairs of alternative is performed in respect to each criterion, to give the matrix $\mathrm{A}$ in which a comparison element $a_{i j}$ represents the ratio of the weight of the coefficient $A_{i}$ alternative compared to the alternative of $A_{j}$.

$$
A=\bigsqcup_{i j}=\left[\begin{array}{cccc}
1 & a_{12} & \cdots & a_{1 n} \\
1 / a_{12} & 1 & \cdots & a_{2 n} \\
\cdots & \cdots & \cdots & \cdots \\
1 / a_{1 n} & 1 / a_{2 n} & \cdots & 1
\end{array}\right]
$$

The elements $A_{i j}$ represent the relationship between the weight coefficients $w_{i} / w_{j}$ where $w$ is the weight vector of each alternative.

The matrix has a reciprocal properties, in which the $a_{j i}=1 / a_{i j}$.

After the comparison, weight coefficients are calculated and vector of coefficients is obtained $w=\left[w_{1}, w_{2}, \ldots, w_{n}\right]$ which is calculated on the basis of Saati procedure in two steps.

First, the matrix of pairs comparison $A=\left[a_{i j}\right]_{n x n}$ is normalized, then weights are calculated.

The normalization is performed by the following equation:

$$
a_{i j}^{*}=a_{i j} / \sum_{1}^{n} a_{i j}
$$

for all $j=1,2, \ldots, n$.

Weight coefficients are calculated by the following equation:

$$
w_{i}=\sum_{1}^{n} a_{i j}^{*} / n
$$

for all $j=1,2, \ldots, n$.

After the comparison, the Consistency Ratio is checked. Consistency Ratio should have a value lower than 0.1. Otherwise, they must reconsider the values that are entered into a matrix of comparison.

Consistency Ratio is calculated as follows:

$$
C I=\boldsymbol{Q}_{\max }-n \geq \mathbf{Q}-1
$$




\section{RESULTS OF THE SELECTION OF THE OPTIMAL MODEL OF IMS}

where $\lambda_{\max }$ is an important parameter of the AHP method and it is used as a reference index for displaying information when calculating the Consistency Ratio (CR). CR is calculated as follows:

$$
C R=C I / R I
$$

where $R I$ represents the random consistency index obtained randomly from comparison matrices.

The final ranking of alternatives is made by synthesis of results from all levels.
After defining the criteria and models of IMS (alternatives) it is performed their evaluation and ranking by AHP method. Criterium DecisionPlus software was used for calculation.

The first step is defining the multidimensional hierarchical structure of objectives, criteria and alternatives - Figure 5.

Thereafter, the weight coefficient of criteria is calculated according to the scale of comparison given in Table 1 . The comparison results are shown in Table 2 and Table 3.

Table 2 Definition of weight coefficient of criteria

\begin{tabular}{|c|c|c|c|c|}
\hline Criteria & C1 & C2 & C3 & C4 \\
\hline C1 & 1 & $1 / 5$ & 5 & 2 \\
\hline C2 & & 1 & 8 & 5 \\
\hline C3 & & & 1 & $1 / 5$ \\
\hline C4 & & & & 1 \\
\hline
\end{tabular}

Table 3 Results of weight coefficients criteria

\begin{tabular}{|l|c|c|c|c|}
\hline Criteria & C1 & C2 & C3 & C4 \\
\hline Weight coefficients & 0.193 & 0.624 & 0.045 & 0.138 \\
\hline Consistency Ratio & \multicolumn{4}{|c|}{$0.084<0.1$} \\
\hline
\end{tabular}

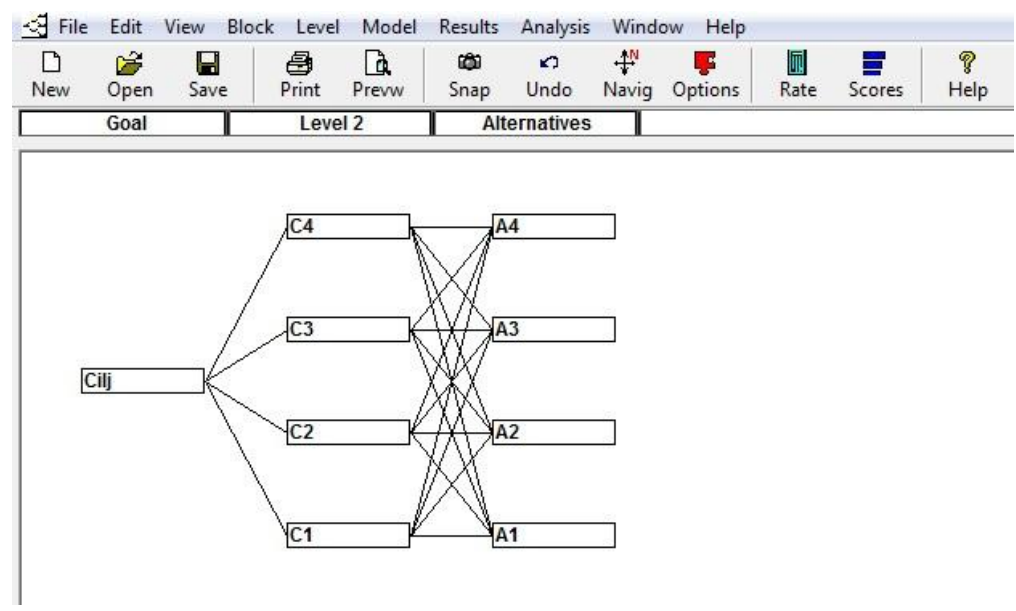

Figure 5 Decision-making hierarchy (Criterium DecisionPlus software) 
In the next step, a comparison of models of IMS (alternatives) is done with

regard to all four criteria defined - Table 4-7.

Table 4 Comparison of alternatives with regard to a criterion Cl

\begin{tabular}{|c|c|c|c|c|}
\hline Alternatives & A1 & A2 & A3 & A4 \\
\hline A1 & 1 & 2 & 1 & 1 \\
\hline A2 & & 1 & 2 & $1 / 2$ \\
\hline A3 & & & 1 & $1 / 3$ \\
\hline A4 & & & & 1 \\
\hline Consistency Ratio & \multicolumn{4}{|c|}{$0.077<0.1$} \\
\hline
\end{tabular}

Table 5 Comparison of alternatives with regard to a criterion C2

\begin{tabular}{|c|c|c|c|c|}
\hline Alternatives & A1 & A2 & A3 & A4 \\
\hline A1 & 1 & $1 / 3$ & $1 / 5$ & 1 \\
\hline A2 & & 1 & $1 / 3$ & 3 \\
\hline A3 & & & 1 & 7 \\
\hline A4 & & & & 1 \\
\hline Consistency Ratio & \multicolumn{3}{|c|}{$0.012<0.1$} \\
\hline
\end{tabular}

Table 6 Comparison of alternatives with regard to a criterion C3

\begin{tabular}{|c|c|c|c|c|}
\hline Alternatives & A1 & A2 & A3 & A4 \\
\hline A1 & 1 & 3 & 5 & 1 \\
\hline A2 & & 1 & 3 & $1 / 3$ \\
\hline A3 & & & 1 & $1 / 5$ \\
\hline A4 & & & & 1 \\
\hline Consistency Ratio & \multicolumn{5}{|c|}{$0.016<0.1$} \\
\hline
\end{tabular}

Table 7 Comparison of alternatives with regard to a criterion $C 4$

\begin{tabular}{|c|c|c|c|c|}
\hline Alternatives & A1 & A2 & A3 & A4 \\
\hline A1 & 1 & $1 / 3$ & $1 / 3$ & 1 \\
\hline A2 & & 1 & 1 & 3 \\
\hline A3 & & & 1 & 3 \\
\hline A4 & & & & 1 \\
\hline Consistency Ratio & \multicolumn{3}{|c|}{$0.00<0.1$} \\
\hline
\end{tabular}

Finally, after the all calculations, the results of ranking are obtained - Table 8 . The best solution is alternative A3 (The process model of IMS). In the second place is an

alternative A2 (Karapetrovic's model), in the third place is an alternative A4 (EFQM excellence model) and on the last place is an alternative A1 (Wilkinson-Dale's model).

Table 8 The final rank of models of IMS

\begin{tabular}{|c|l|c|}
\hline No. & \multicolumn{1}{|c|}{ Model of IMS } & Result \\
\hline 1. & A3 (The process model of IMS) & 0.449 \\
\hline 2. & A2 (Karapetrovic's model) & 0.246 \\
\hline 3. & A4 (EFQM excellence model) & 0.157 \\
\hline 4. & A1 (Wilkinson-Dale's model) & 0.148 \\
\hline
\end{tabular}




\section{THE ANALYSIS OF RESULTS}

Analysis includes criteria and their impact on the ranking of the models of IMS, as well as the models of IMS itself.

When analyzing the criteria, the most important are their weights, because that is their measure of influence on the result of ranking of alternatives or models of IMS. Table 3. shows that the criterion $\mathrm{C} 2$ (the expected effects of the IMS) has the greatest impact on the result of the ranking because its weight coefficient is 0.624 . This means that it affects with $62.4 \%$ for a decision with regard to other criteria. Also, this shows that in the selection of the optimal model of IMS, the most important is what will the mining companies get after its implementation, i.e. which the positive effects companies will achieve.

In the second place is the criterion $\mathrm{C} 1$ (the cost of implementation of the IMS), which affects $19.3 \%$ on the result of ranking. This shows that the costs of implementation of the optimal model of IMS is very important for mining companies, considering that they are in a difficult financial situation.

In the third place is criterion C4 (the applicability of the model), which affects with $13.8 \%$ on the process. This shows that it is very important to the mining companies the suitable level of a particular model of IMS for use in conditions in which they operate. Implementation of the IMS requires forming a team for implementation, the acquisition of new knowledge, application of new methods, management and procedures, overcoming resistance, implementation and control of the obtained results.

Finally, the least influential is the criterion $\mathrm{C} 3$ (the time required for implementation of the IMS) with weight ratio of 0.045 . This shows that the time required for the implementation of IMS, although important, are in the background compared to other effects that are expected from this system.

The analysis of the final ranking of alternatives (model IMS) starts from the optimal (best) alternative. It is the alternative A3 (the process model of IMS) which has the highest value of the results of 0.449 . The reason is that this model focuses precisely on that what is the strongest feature of mining companies - the existence and continuous performing of very complex and many processes during the work. Processes are the place where most can be done, which is the goal of this model. On the other hand, this model of IMS integrates various systems such as QMS, EMS, OHSAS, and all employees of the companies. All this enables significantly improvements of performances of mining companies in most or all areas of their functioning.

The second highest ranking of alternative is A2 (Karapetrovic's model). It discusses the integration of five systems - QMS, EMS, OHSAS, corporate social responsibility management system (CSRMS) and financial management system (FMS) and it is turned towards the continuous improvement process. Unlike the previous model, it is more complex, more demanding and less suitable for mining companies in our country.

In third place is the alternative A4 (EFQM excellence model), while in the last place is alternative A1 (Wilkinson -Dale's model). The difference in the results between these models is small. Their disadvantage compared to the previous two models of IM is that they to a lesser extent consider the processes, then they are less adapted to mining companies and therefore, they can provide the lower results. The good side of these models is that they integrate into their structures the environmental management system, which is very important for mining companies

\section{CONCLUSION}

Authors have conducted the multiple criteria decision-making method in order to select the optimal model of Integrated Management System (IMS) in mining companies in Serbia. Selection of the optimal model of IMS is one of the most important strategic decisions of mining companies. Four models of IMS are analyzed: Wilkinson Dale's model (alternative A1), Karapetro- 
vic's model (alternative A2), the process model (alternative A3) and the EFQM excellence model (alternative A4). Four criteria for the ranking are also considered : the cost of implementation of the IMS (criterion C1), the expected effects of the IMS (criterion $\mathrm{C} 2$ ), the time required for implementation of the IMS (criterion C3) and the applicability of the model (criterion 4).

Ranking of models of IMS was performed by the AHP method for multiple criteria decision making. In this method, weight coefficient of criteria for ranking is calculated first, then the proposed models of IMS are assessed and their full ranking is done.

The applied method for multiple criteria analysis -AHP, can be of great help to decision-makers because it allows easy and high quality analysis of influential factors and parameters. The best model of IMS for mining companies in Serbia chosen based on the results of AHP method was the process model (alternative A3). The most influential criteria for a complete ranking of alternatives (IMS models) are the expected effects of the IMS (criterion C2) and the cost of implementation of the IMS (criterion $\mathrm{C} 1$ ).

\section{REFERENCES}

[1] Djekic, V. et al., Importance of Interoperability Information and Information Systems in the Implementation of the Model IMS. International Scientific Conference Managament, Mladenovac, Serbia (2012) 171-175;

[2] Heleta M., Quality Management, Singidunum University, Belgrade, Serbia (2008) 5;

[3] Brzakovic M., Interoperability and Information Security in Organizations of Strategic Importance in Emergency Situations-Doctoral Dissertation, Faculty of Security, Belgrade, Serbia (2009);

[4] Volanovic S., The Development of a General Model for the Implementation of the Integrated Management System Based on Risk Assessment Processes in Organizations, Doctoral Dissertation, Faculty of Technical Sciences, Novi Sad, Serbia (2014);
[5] Saaty T.L., The Analytical Hierarchy Process, New York: McGraw-Hill (1980);

[6] Bogdanovic D. et al., Selection the Optimum Method of Rehabilitation the Degraded Ore as around the Bor River Downstream from the Flotation Tailing Dump Bor. Journal of Mining and Metallurgy Engineering Bor, 4 (2014) 137-146;

[7] Wilkinson G., Dale B., Integrated Management Systems: a Model Based on Total Quality Approach, Managing Service Quality, 11(5) (2001) 318-330;

[8] Hofstede G. H., Culture's Consequences: Comparing Values, Behaviors, Institutions and Organizations Across nations. Ed. Geert Hofstede. Sage (2001);

[9] https://scholar.google.com/citations? user=Q2V0P6oAAAAJ\&hl=en\&oi= ao (accessed 13.05.2015)

[10] Paunkovic J., Educational Programs for Sustainable Societies Using CrossCultural Management Method, Global Sustainable Communities Handbook: Green Design Technologies and Economics (2014): 387- Butterworth Heinemann imprint of Elsevier, Elsevier Copyright (C) 2014;

[11] Paunkovic J., Zikic S., Cvetkovic A., Sustainable Utilization of Health Care Technologies is Influenced by Organizational and Cultural Factors - A Case Study. Advances in Biomedicine and Health Science, (2013) 57;

[12] Karapetrovic S., Measuring of Integrated Management Systems, Measuring Business Excellence, 7(1) (2003) 4-13;

[13] Karapetrovic S., Jonker J., Integration of Standardized Management Systems: Searching for a Recipe and Ingredients, Total Quality Management, 14(04) (2003) 451-459;

[14] Petrovic M., The Process Approach to Integrated Management, 33. National Conference on Quality: Quality Festival, AQS and Quality Centre, Kragujevac, Serbia (2008);

[15] European Foundation for Quality Management (EFQM), EFQM Model for Business. 


\begin{tabular}{ll}
\hline \hline INSTITUT ZA RUDARSTVO I METALURGIJU BOR & ISSN: 2334-8836 (Štampano izdanje) \\
UDK: 622 & ISSN: 2406-1395 (Online) \\
\hline \hline
\end{tabular}

Slavica Miletic , Dejan Bogdanovic ${ }^{* *}$, Jane Paunkovic ${ }^{* * * *}$

\section{IZBOR OPTIMALNOG MODELA INTEGRISANOG ODRŽIVOG SISTEMA MENADŽMENTA U RUDARSKIM KOMPANIJAMA******}

\section{Izvod}

U radu je primenjena multikriterijumska analiza za izbor optimalnog modela integrisanog sistema menadžmenta u cilju poboljšanja performansi rudarskih kompanija. Integrisani sistem menadžmenta koji predstavlja proces integracije različitih sistema menadžmenta u savremanom poslovanju su postala obaveza svake kompanije radi opstanka na tržištu. Savremene kompanije koje su implementirale integrisani sistem menadžmenta bolje funkcionišu, imaju uređene procese, poboljšavaju svoju strukturu $i$ kulturu radi izvršenja aktivnosti upravljanja $i$ stalnog unapređenjasvih procesa.

Rudarske kompanije u našoj zemlji se nalaze u vrlo teškoj situaciji. Njihovo poslovanje je vrlo specifično, jer se one karakterišu velikom složenošću, zastarelim i kompleksnim organizacionim strukturama, neodgovarajućim načinom upravljanja, rada, funkcionisanja $i$ dr. Polazé́i od toga, $u$ ovom radu su predložena četiri modela integrisanog sistema menadžmenta koji su primenljivi u rudarskim kompanijama, a u cilju poboljšanja njihovih performansi. Takođe, definisani su odgovarajući kriterijumi za izbor optimalnog modela. Za izbor i rangiranje modela integrisanog sistema menadzmenta je primenjena AHP metoda. Dobijeni rezultat daje optimalni model integrisanog sistema menadžmenta koji je primenljiv $i$ koji može da ostvari najbolje rezultate u cilju poboljšanja performansi rudarskih kompanija u našoj zemlji.

Ključne reči: integrisani sistem menadžmenta, rudarstvo, AHP metoda

\section{UVOD}

U zadnje vreme se velika pažnja poklanja implementiranju Integrisanog sistema menadžmenta (ISM) koji je sastavljen od različitih sistema menadžmenta. Integrisani sistem menadžmenta se definiše kao sveobuhvatni alat menadžmenta koji povezuje sve elemente poslovnog sistema u jedinstven i celovit sistem upravljanja procesima $u$ organizaciji a radi zadovoljavanja zahteva zainteresovanih strana [1]. Danas postoji više modela imlementacije ISM-a koji su nastali na osnovu specifičnih zahteva stejkholdera i samih kompanija. Kompanije koje su implementirale za njih optimalni model ISM-a imaju značajne koristi od toga, kao što su: stalno poboljšanje procesa, dobijanje jedinstvenog kvaliteta proizvoda $\mathrm{i}$ usluga, poboljšanje organizacione kulture,

\footnotetext{
* Institut za rudarstvo i metalurgiju Bor

** Univerzitet u Beogradu-Tehnički Fakultet u Boru

**** Megatrend Univerzitet-Fakultet za menadžment Zaječar

***** Ovaj rad je proistekao kao rezultat projekta TR34023 "Razvoj tehnoloških procesa prerade nestandardnih koncentrata bakra u cilju optimizacije emisije zagađujućih materija" finansiranog od strane Ministarstva prosvete, nauke i tehnološkog razvoja Republike Srbije
} 
veći stepen zadovoljstva zainteresovanih strana i dr. Kvaliet predstavlja koncept za održivi razvoj koji uspostavlja bilans između tehnološkog razvoja neophodnog za ekonomski prospertitet i opstanka životne sredine i društva u celini [2]. Ključna pitanja za menadžment rudarskih kompanijasu kako uskladiti sistem menadžmenta sa različitim standardima, zatim kako izvršiti međusobno interno usklađivanje parcijalnih sistema menadžmenta kompanije, kako iskoristiti već implementirani sistem i nakraju, kako izabrati optimalni model ISM-a. Rudarske kompanije zbog svoje specifičnosti moraju prvo da identifikuju zahteve zainteresovanih strana, a onda, na osnovu toga da dođu do optimalnog modela implementacije ISM-a. Pošto su svi elementi standardizovanih sistema menadžmenta međusobno kompatabilni, to omogućuje da svi parcijalni sistemi menadžmenta čine jedinstveni integrisani menadžment sistem (ISM) u kom postoje jake međusobne veze između pojedinih elemenata sistema [3]. Shodno tome, sistem integrisanog menadžmenta se uspostavlja kroz opredeljenost menadžmenta organizacije za implementaciju zahteva standarda, širenje svesti o značaju uređenja procesa i stalnog poboljšanja poslovnih procesa čime se stvaraju uslovi za uspeh.

Poslovnom uspehu rudarskih kompanija prethodi pravilan izbor optimalnog modela ISM-a koji će tokom vremena doneti značajna poboljšanja kao što su veći stepen zadovoljstva svih zainteresovanih strana od vlasnika, menadžera, pa do krajnjeg korisnika proizvoda i usluga, odnosno potrošača ili kupca.

\section{MODELI INTEGRISANOG SISTEMA MENADŽMENTA}

Danas postoji veliki broj modela ISM-a koji su uspešno primenjeni u poslovnim kompanijama. Osnovni modeli ISM-a su prvobitno bili sistem menadžmenta kvaliteta (standard ISO 9001) i sistem upravljanja zaštitom životne sredine (standard ISO 14001), da bi kasnije došlo do integracije i sistema upravljanja zdravljem i bezbednošću na radu (standard OHSAS 18001). Daljim razvojem se došlo do stvaranja novih modela ISM-a koji uzimaju u obzir vrstu delatnosti određene kompanije, kao i sve zainteresovane strane ili stejkholdere. Sistem koji u sebe integriše zahteve više standarda prvenstveno obezbeđuje zadovoljenje zahteva više zainteresovanih strana zato što je čest slučaj da različite zainteresovane strane zahtevaju različite sisteme upravljanja, tj. sisteme upravljanja usaglašene samo sa određenim standardom ili standardima [4].

$\mathrm{U}$ ovom radu se direktno obrađuje održive rudarske kompanije sa aspekta implementacije optimalnog modela ISM-a pomoću Analitičko Hijerarhijskog Procesa (AHP metoda). AHP je jedna od metoda višekriterijskog odlučivanja za donošenje odluka pri izboru najpovoljnijeg rešenja između više alternative [5]. Prednost ove metode je u tome što ona može istovremeno da razmatra i finansijske i nefinansijske faktore pri postupku izbora optimalnog modela ISM-a [6]. Kao alternative su ovde razmatrana četiri modela IMS-a koji su uspešno primenjeni u razvijenim zemljama. Ovi modeli su zasnovani na osnovnim postavkama i procesnom pristupu tako da se iz toga razvija proces integracije menadžmenta.

\subsection{Wilkinson-Dale-ov model (Alternativa A1)}

Sistemi integracija kod Wilkinson Dale-ovog modela su: sistem menadžmenta za kvalitet (QMS), sistem menadžmenta zaštite životne sredine (EMS) i sistem menadžmenta zaštitom zdravlja i bezbednosti na radu (OHSAS) [7] - slika 1. Diferencijacija i specifičnost ovog modela je u tome što on 
uključuje integrisanu kulturu i elemente modela TQM-a (Total Quality Managamenat). Wilkinson - Dale-ov model integracije zavisi od zahteva i politike svake organizacije, odnosno od zainteresovanih strana. Zainteresovane strane mogu biti menadžeri (uspešno poslovanje), sami zaposleni (zarade, uslovi rada), dobavljači (dugoročna saradnja), kupci (kvalitet i cena proizvoda), društvena zajednica (životna sredina), vlasnici (profit) i dr. Ovaj model može da implementira svaka organizacija koja uzima sistem kvaliteta, sistem zaštite životne sredine i sistem zaštite zdravlja i bezbednost na radu kao prioritet u svom poslovanju. Takođe, ovaj model može da implementiraju i organizacije koje su uključene u aktivnosti TQM-a radi kontinualnih poboljšavanja.
Wilkinson i Dale u ovom modelu daju veliki značaj održivoj kulturi za integraciju kako bi moglo doći do stvaranja kulturnih organizacija što pomaže brzom implementtiranju samog sistema integracije.

Za rudarsku kompaniju koja implementira ISM je jako bitno da ima ugrađen model "nacionalne kulture", jer to može dovesti do uspešne realizacijeovog procesa. Koliko je značajan i relevantan odnos organizacione i nacionalne kulture govori podatak o citiranosti Hofstedovih radova [8]. On je najcitiraniji autor iz oblasti društvenih nauka (123707 citata - Google Scholar [9]). Autori ovog rada su objavili rezultate svojih istraživanja o povezanosti organizacione i nacionalne kulture u Srbiji u više oblasti $[10,11]$.

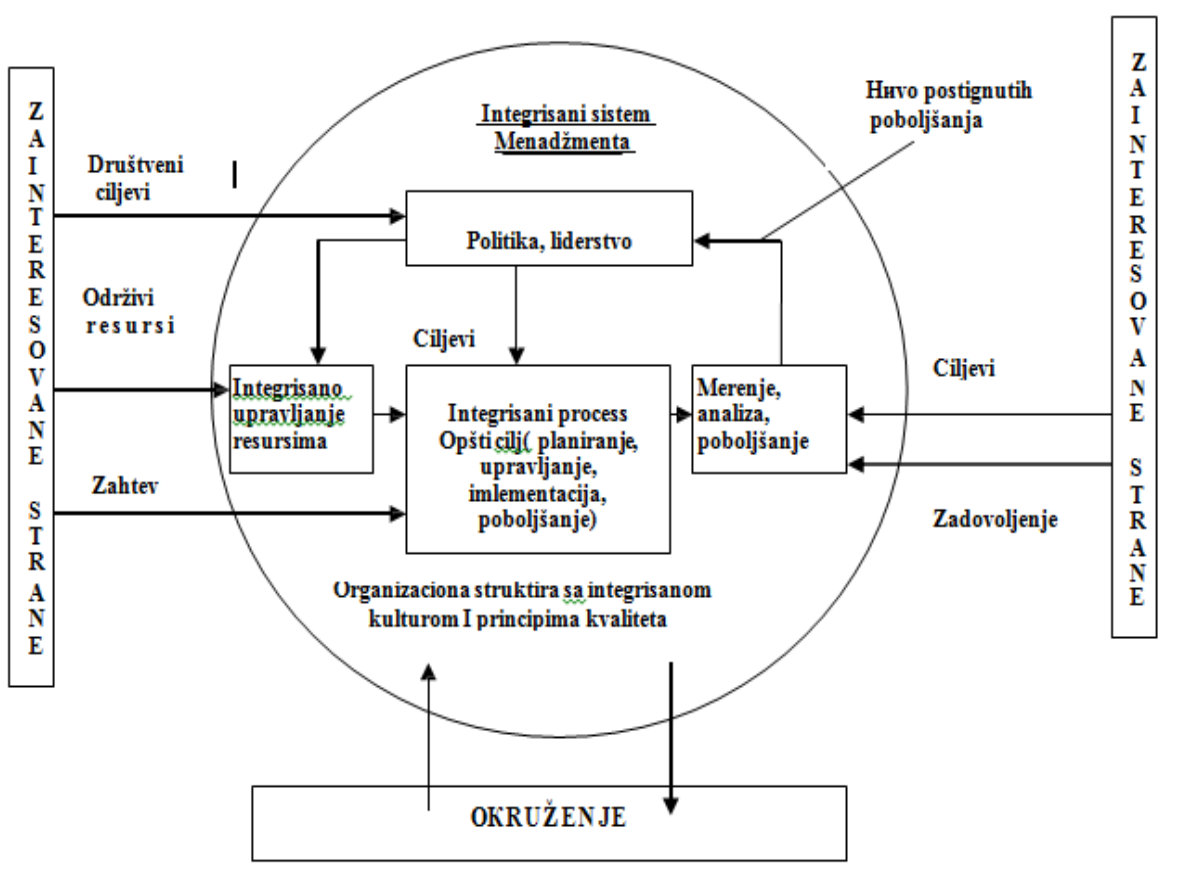

S1. 1. Prošireni Wilkinson - Dale model ISM - a [13] 


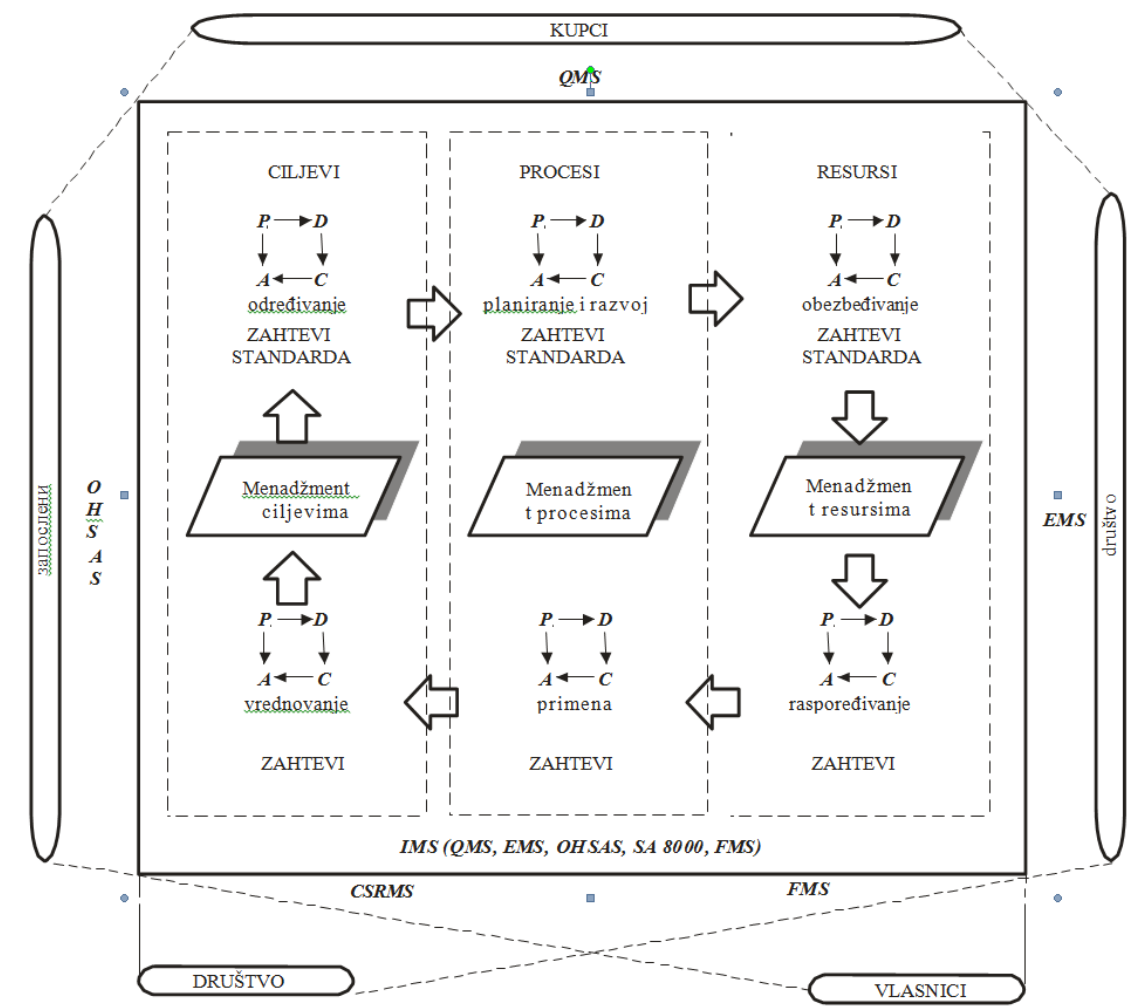

S1. 2. Model IMS - a Karapetrovića

\subsection{Model Karapetrovića \\ (Alternativa A2)}

Kod ovog modela su uključena pet sistema integracije - QMS, EMS, OHSAS, korporacijski menadžment sistem socijalne odgovornosti (CSRMS) i finasijski sistem menadžmenta (FMS). To znači da su uključeni zahtevi standarda i zahtevi zainteresovanih strana. Model se zasniva na sistematskom pristupu i ciklusu PDCA planiraj, uradi, proveri i deluj - unapredi.

Kod modela Karapetrovića, osim kupaca, fokus je usmeren i na zadovoljenje interesne grupe društvene zajednice (zaštita životne sredine), zaposlenih (smanjenja povreda na radu), menadžmenta (smanjenje rizika poslovanja), kao i drugih zaintereso- vanih strana $[9,10]$. Realizacija menadžment sistema se vrši kroz upravljanje prema ciljevima, upravljanje procesima i upravljanje resursima - slika 2. Model Karapetrovića je kompatabilan sa PDCA pristupom sistema menadžmenta, jer on razmatra sve procese sa ciljem njihovog stalnog unapređenja i poboljšanja. Ti procesi su: određivanje ciljeva, planiranje i razvoj procesa, obezbeđivanje resursa, raspoređivanje menadžment resursa, primena u menadžment procesima i vrednovanje menadžment ciljeva.

Ovaj model je primenljiv za sve industrijske kompanije - proizvodne i uslužne delatnosti. 
Karakteristike kompanija (vrste delatnosti kompanija, njihove specifičnosti, veličine i zahteva interesnih grupa) su uslovile razvoj novih standardizovanih menadžment sistema (MSS - Managament Systems Standards) za zadovoljenje njihovih specifičnih zahteva i lakšeg implementiranja ISM-a.

\subsection{Procesni model (Alternativa A3)}

Kod procesnog modela svaki od procesa, podprocesa i aktivnosti imaju ulaze, a to su zahtevi stejkholdera i izlaze - zadovoljstvo stejkholdera -slika 3. U toku realizazacije proizvoda vrše se merenja, analize i poboljšanja uz odgovornost rukovodstva sa odgovarajućim resursima, stalnim poboljšanjem sistema menadžmenta i dr.

Prema [11] sisteme menadžmenta koji se baziraju na suštini procesnog pristupa iz ISO 9000 je moguće indetifikovati kroz strategiju integracije.

Specifičnosti kod procesnog modela se ogledaju kroz primenu procesnog pristupa, a integriše se $\mathrm{N}$ sistema $\mathrm{i}$ to: QMS, EMS,
OHSAS i sistem menadžmenta bezbednosti hrane (HACCP). Ovi standardi imaju sličnosti u okviru njihove strukture tako da je integraciju standarda moguće izvesti na osnovu identičnih i specifičnih zahteva na koje se mora odgovoriti pri upravljanju procesa. To je razlog što procesni pristup predstavlja novi pristup menadžmenta. Suština standarda za sisteme menadžmenta (ISO 9001, ISO 14001, OHSAS 18001 i ISO 22000) upravo je u upravljanju procesima.

Procesni model prilikom implementiranja zahteva poznavanje procesa organizacije, zahteve interesne grupe, definisanje metodologije upravljanja, određivanje neophodnih resursa i sprovođenje svih procedura uz stalno unapređivanje i poboljšanje. Pri implementiranju procesnog modela ISM-a za dokumentaciju, realizaciju zahteva (proizvoda ili usluga) i merenja zadovoljstva stejkholdera odgovorni su osoba koja je zadužena, vlasnik procesa ili menadžer, a za realizaciju zaposleni i svi učesnici procesa.

U našoj zemlji je najviše zastupljen ovaj model ISM-a i to u 96,23\% preduzeća.

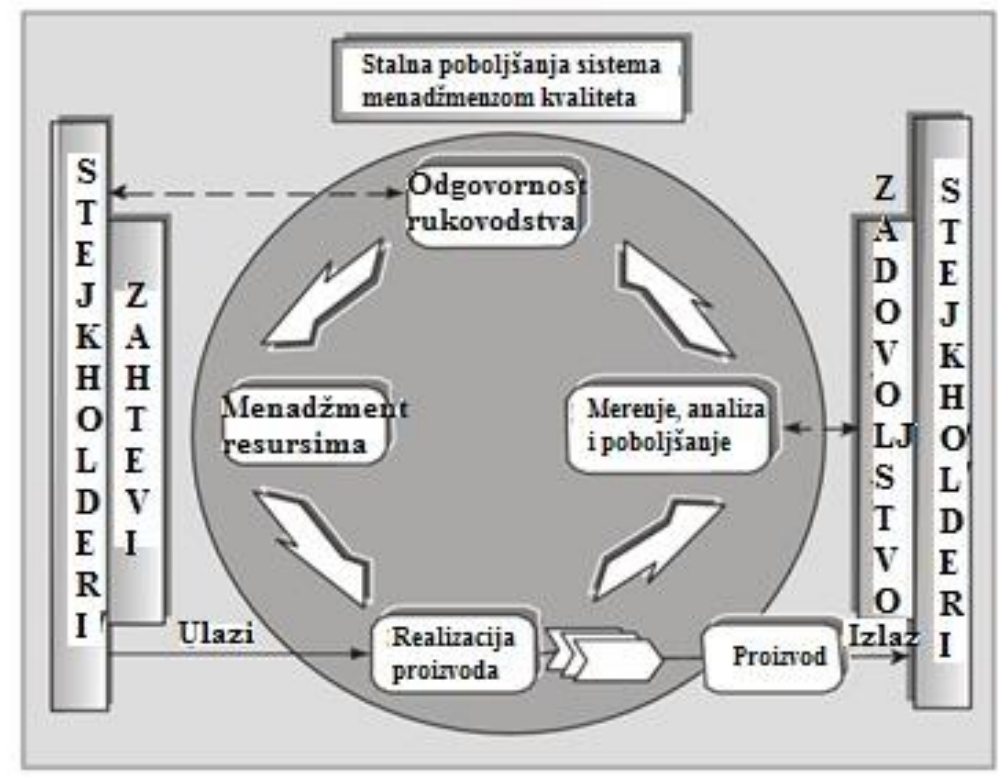

Sl. 3. Model sistema menadžmenta kvalitetom zasnovan na procesima [14] 


\subsection{EFQM model izvrsnosti}

(Alternativa A4)

EFQM model izvrsnosti je izgradila Evropska fondacija za mendžment kvaliteta 1992. godine i unapređen je 1999. godine. Model služi kao osnova za dodelu evropske nagrade za kvalitet i to za:

- velike kompanije $\mathrm{i}$

- mala i srednja preduzeća.
Za razliku od drugih, ovaj model ima za bazu filozofiju menadžmenta totalnim kvalitetom (TQM) i zasniva se na integraciji dva sistema (interoperabilnost) $i$ to sistema menadžmenta kvalitetom i sistema menadžmenta životnom sredinom (EFQM, 1998. EFQM, 2002.) - slika 4.

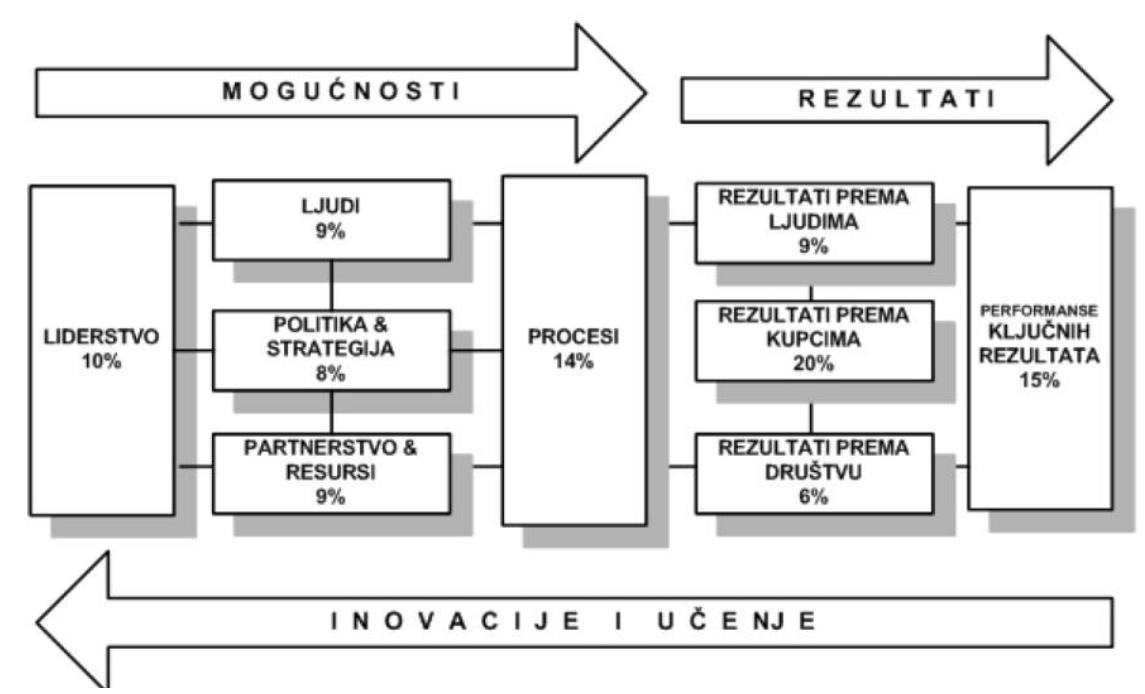

Sl. 4. EFQM model izvrsnosti [15]

Ovaj model ima devet kriterijuma pri čemu se pet odnose na mogućnosti koji pokazuju šta kompanija radi, dok se ostali odnose na rezultate. Rezultati pokazuju u kojoj meri organizacija koristi mogućnost.

Model EFQM je primenljiv kod onih kompanija čiji su zahtevi takvi da mogu da izgrade sopstvene pristupe u postizanju izvrsnosti. Unutar ovog modela ima nekoliko baznih koncepta koji su obavezni za njegovu primenu, a to su:

- orijentisanost na rezultate, gde rezultati pokazuju izvrsnost koji su zadovoljstvo stejkohldera;
- fokusiranost na kupce, gde je izvrsnost kreiranje postojanog kupca;

- liderstvo i postojanost odlučnosti, gde je izvrsnost u liderstvu sa postojanim odlikama;

- menadžment procesima i činjenicama, gde je izvrsnost upravljanje kompanijom na osnovu procesa $\mathrm{i}$ činjenica;

- uključivanje zaposlenih i njihov razvoj, gde je izrsnost u motivisanju zaposlenih radi povećanja doprinosa;

- poboljšanje, inovacije i stalno edukacija, gde do izvrsnosti dovodi kreiranje 
inovacija i mogućnost za savremenije poslovanje;

- razvoj partnerstva, gde se izvrsnost manifestuje kroz razvoj i održavanje partnerstva uz povećavanje vrednosti;

- društvena odgovornost, gde se izvrsnost ogleda u prevazilaženju nekih minimalnih obaveza u društvu i gde kompanija teži odgovornijem razumevanju zahteva društva.

Kriterijumi za ostvarenje poslovne izvrsnosti su: liderstvo, ljudi, politika i strategija, partnerstvo i resursi, procesi, rezultati prema kupcima i društvu i na kraju rezultati koji su zadovoljstvo svih zainteresovanih strana.

Zajedničke karakteristike modela EFQM, procesnog modela, modela Karapetrovića i modela Wilkinson - Dale su: sistemski pristup, stalna poboljšanja, zadovoljenje zahteva svih zainteresovanih strana, smanjenje obimne dokumentacije i to što oni nemaju ograničenja u pogledu vrste organizacije uključujući i rudarske kompanije.

\section{DEFINISANJE KRITERIJUMA \\ ZA IZBOR OPTIMALNOG MODELA ISM-A}

Kriterijumi sadrže najvažnije karakteristike za izbor optimalnog modela implementacije ISM-a u rudarskim kompanijama, a to su:

Troškovi uvođenja ISM-a (kriterijum C1) je vrlo važan factor za donošenje odluke pri izboru optimalnog modela ISM-a. Troškovi uvođenja se određuju za svaki predloženi model ISM-a u rudarskim kompanijama i njihov uticaj je srazmeran dobijenim rezultatima.

Očekivani efekti ISM-a (kriterijum C2) je jako bitan faktor koji ima veliki uticaj pri donošenju odluke pri izboru optimalnog modela implementiranja ISM-a. Rudarske kompanije implementacijom optimalnog modela ISM-a treba da ostvare značajna poboljšanja, kao što su: izgradnja modela „nacionalne kulture“, bolja realizacija svoje politike i strategije, veće zadovoljstvo zapo- slenih, smanjenje povreda na radu, stalna poboljšanja resursa (materijalnih, finasijskih i ljudskih), kontinualno poboljšanje procesa poslovanja, poboljšanje upravljanja kompanijom, zadovoljniji eksterni i interni kupci, bolji odnos prema društvu, poboljšanje zaštite životne okoline, poslovanje po svim propisima i pravilima, mogućnost poslovanja na globalnom tržištu, prednost prilikom učešća na tenderu, smanjenje troškova i dr.

Vreme implementacije ISM-a (kriterijum C3) je takođe, veoma važan faktor koji značajno utiče na izbor optimalne metode ISM-a. Na primer, ako se izabrani model imlementira duži vremenski period od predviđenog, nekim od zainteresovana strana neće biti ispunjeni zahtevi, što povlači da se njihovo nezadovoljstva odražava na ostale, tako da sve to dovodi do loše reputacije rudarske kompanije u okviru društvene zajednice. Neki od ovih modela ISM-a imaju kraći period implementiranja što može da bude veoma značajno za rudarske kompanije.

Primenljivost modela (kriterijum C4) je kriterijum koji ukazuje na stepen mogućnosti implementacije određenog modela ISM-a u rudarskim kompanijama. Neke modele je lakše implementirati, a druge teže. Cilj je da rudarska kompanija izabere onaj model koji nije težak za implementaciju i koji će joj dugoročno doneti mnogobrojne koristi. Pri tome, rudarska kompanija mora da uzme u obzir mnogobrojne faktore, kao što su određene njene specifičnosti, nivo opremljenosti, struktura radne snage, menadžment kompanije i dr.

\section{AHP METOD}

AHP je kvantitativna tehnika koja omogućava strukturiranje kompleksnog problema odlučivanja sa više kriterijuma i pruža objektivnu metodologiju koja se primenjuje na širok spektar odluka.

AHP polazi od dekompozicije složenog problema odlučivanja u višedimenzionalnu hijerarhijsku strukturu ciljeva, kriterijuma i 
alternativa. Nakon toga, vrši se procena uticaja kriterijuma, onda se upoređuju alternative u odnosu na svaki kriterijum i vrši se konačno rangiranje alternativa.

Procena relativnog uticaja svakog kriterijuma i poređenje alternativa $u$ odnosu na kriterijume se vrši preko matrice poređenja. To uključuje: formiranje matrice poređenja na svakom nivou hijerarhije, počev od drugog nivoa nadole; proračun težinskih koeficijenata za svaki element hijerarhije i procena stepena konzistentnosti u cilju provere konzistentnosti celokupnog procesa.

U tom cilju, definiše se skup alternativa $\left\{A_{1}, A_{2}, \ldots, A_{n}\right\}$ i skup težinskih koeficijenata kriterijuma $\left\{\mathrm{w}_{1}, \mathrm{w}_{2}, \ldots, \mathrm{w}_{\mathrm{n}}\right\}$.

Upoređenje kriterijuma i alternativa vrši se na bazi skale sa ocenama od 1 do 9 tabela 1.

Tabela 1. Skala poređenja elemenata odlučivanja

\begin{tabular}{|l|l|}
\hline \multicolumn{2}{|c|}{ Dominantnosti } \\
\hline Opis & Ocena \\
\hline Jednako & 1 \\
\hline Slaba dominacija & 3 \\
\hline Jaka dominacija & 5 \\
\hline Vrlo jaka dominacija & 7 \\
\hline Apsolutna dominacija & 9 \\
\hline $2,4,6,8$ su međuvrednosti \\
\hline
\end{tabular}

Rezultat upoređenja kriterijuma predstavlja matrica koja ima sledeći oblik:

$$
W=\left[w_{i} / w_{j}\right]=\left[\begin{array}{cccc}
w_{1} / w_{1} & w_{1} / w_{2} & \ldots & w_{1} / w_{n} \\
w_{2} / w_{1} & w_{2} / w_{2} & \ldots & w_{2} / w_{n} \\
\ldots & \ldots & \ldots & \ldots \\
w_{n} / w_{1} & w_{n} / w_{2} & \ldots & w_{n} / w_{n}
\end{array}\right]
$$

Nakon toga, vrši se upoređenje parova alternativa u odnosu na svaki kriterijum, pri čemu se dobija matrica poređenja $A$ u kojoj element $a_{i j}$ predstavlja odnos težinskog koeficijenta alternative $A_{i} \mathrm{u}$ odnosu na alternativu $A_{j}$.

$$
A=\downarrow_{i j} \neq\left[\begin{array}{cccc}
1 & a_{12} & \cdots & a_{1 n} \\
1 / a_{12} & 1 & \cdots & a_{2 n} \\
\cdots & \cdots & \cdots & \cdots \\
1 / a_{1 n} & 1 / a_{2 n} & \cdots & 1
\end{array}\right]
$$

Elementi $A_{i j}$ predstavljaju odnos između težinskih koeficijenata $w_{i} / w_{j}$ gde je $w$ vektor težine svake alternative.

Matrica ima recipročna svojstva, kod koje su $\mathrm{a}_{\mathrm{ji}}=1 / \mathrm{a}_{\mathrm{ij}}$.

Posle izvršenog upoređenja računaju se težinski koeficijenti i dobija se vektor koeficijenata $w=\left[w_{1}, w_{2}, \ldots, w_{n}\right]$ koji se računa na bazi Satijeve procedure $u$ dva koraka.

Prvo, matrica upoređenja parova $A=\left[a_{i j}\right]_{n x n}$ se normalizuje, a zatim se izračunavaju težine.

Normalizacija se vrši pomoću sledećeg obrasca:

$$
a_{i j}^{*}=a_{i j} / \sum_{1}^{n} a_{i j}
$$

za sve $j=1,2, \ldots, n$.

$\mathrm{Za}$ izračunavanje težinskih koeficijenata koristi se sledeći obrazac:

$$
w_{i}=\sum_{1}^{n} a_{i j}^{*} / n
$$

za sve $j=1,2, \ldots, n$.

Nakon upoređenja, vrši se provera stepena konzistentnosti. Stepen konzistentnosti treba da ima vrednost manju od 0,1 . U suprotnom, moraju se ponovo razmatrati vrednosti koje su unete $\mathrm{u}$ matricu poređenja.

Stepen konzistentnosti se računa na sledeći način

$$
C I=Q_{\max }-n \geq \mathbf{Q}-1
$$

gde $\lambda_{\max }$ predstavlja značajan parametar kod AHP metode i on se koristi kao referentni 


\section{REZULTATI IZBORA \\ OPTIMALNOG MODELA ISM-A}

indeks za prikazivanje informacija kod proračuna stepena konzistentnosti $(C R)$. $C R$ se računa na sledeći način:

$$
C R=C I / R I
$$

gde $R I$ predstavlja slučajni indeks konzistentnosti dobijen nasumice iz matrice upoređenja.

Određivanje konačnog ranga alternativa vrši se sintezom rezultata koji su dobijeni na svim nivoima.
Nakon definisanja kriterijuma i modela ISM-a (alternativa) vrši se njihova ocena i rangiranje primenom AHP metode. Pri tome, za proračun je korišćen softver Criterium DecisionPlus.

Prvi korak je definisanje višedimenzionalne hijerarhijske strukture ciljeva, kriterijuma i alternativa - slika 5 .

Nakon toga vrši se određivanje težinskih koeficijenata kriterijuma uz pomoć skale poređenja koja je data u tabeli 1 . Rezultati poređenja su prikazani u tabelama 2 i 3 .

Tabela 2. Definisanje težinskih koeficijenata kriterijuma

\begin{tabular}{|l|c|c|c|c|}
\hline Kriterijumi & C1 & C2 & C3 & C4 \\
\hline C1 & 1 & $1 / 5$ & 5 & 2 \\
\hline C2 & & 1 & 8 & 5 \\
\hline C3 & & & 1 & $1 / 5$ \\
\hline C4 & & & & 1 \\
\hline
\end{tabular}

Tabela 3. Rezultati težinskih koeficijenata kriterijuma

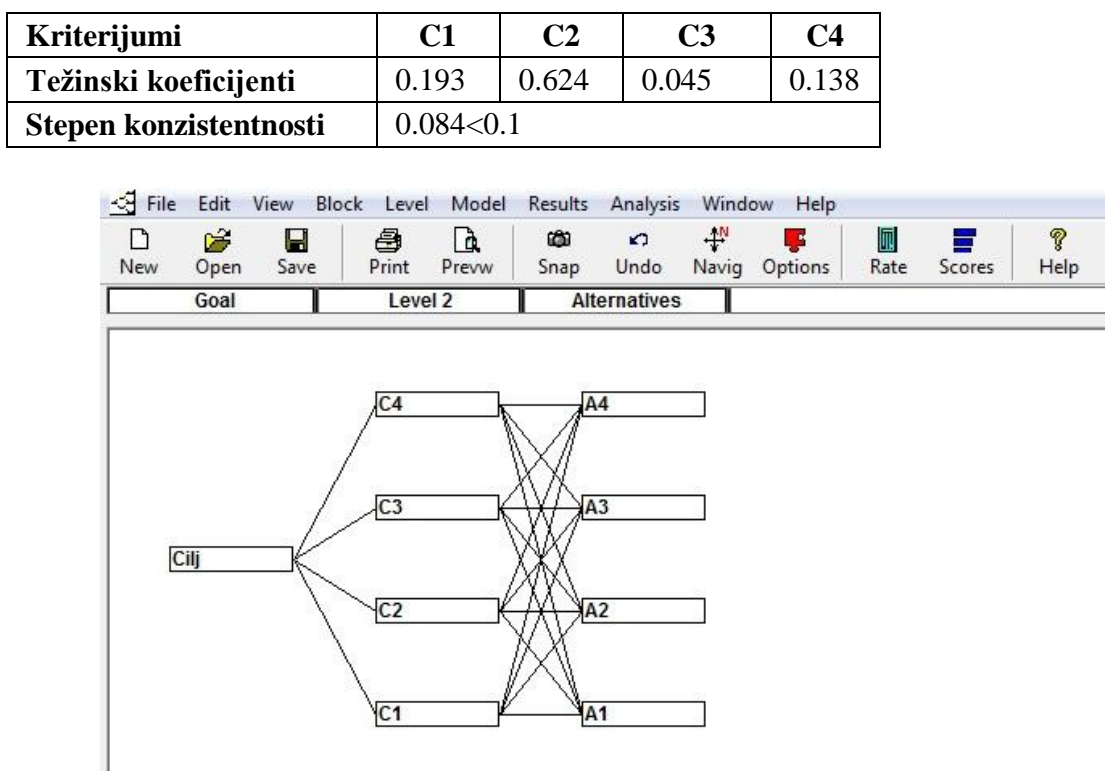

Sl. 5. Hijerarhija odlučivanja (Criterium Decision Plus softver)) 
U sledećem koraku se vrši upoređivanje modela ISM-a (alternativa) $\mathrm{u}$ odnosu na sva četiri definisana kriterijuma - tabele 4 - 7.

Tabela 4. Upoređenje alterntiva u odnosu na kriterijum Cl

\begin{tabular}{|c|c|c|c|c|}
\hline Alternative & A1 & A2 & A3 & A4 \\
\hline A1 & 1 & 2 & 1 & 1 \\
\hline $\mathbf{A 2}$ & & 1 & 2 & $1 / 2$ \\
\hline $\mathbf{A 3}$ & & & 1 & $1 / 3$ \\
\hline $\mathbf{A 4}$ & & & & 1 \\
\hline Stepen konzist. & \multicolumn{3}{|c|}{$0.077<0.1$} \\
\hline
\end{tabular}

Tabela 5. Upoređenje alterntiva u odnosu na kriterijum C2

\begin{tabular}{|c|c|c|c|c|}
\hline Alternative & A1 & A2 & A3 & A4 \\
\hline A1 & 1 & $1 / 3$ & $1 / 5$ & 1 \\
\hline A2 & & 1 & $1 / 3$ & 3 \\
\hline A3 & & & 1 & 7 \\
\hline A4 & & & & 1 \\
\hline Stepen konzist. & \multicolumn{5}{|c|}{$0.012<0.1$} \\
\hline
\end{tabular}

Tabela 6. Upoređenje alterntiva u odnosu na kriterijum C3

\begin{tabular}{|c|c|c|c|c|}
\hline Alternative & A1 & A2 & A3 & A4 \\
\hline A1 & 1 & 3 & 5 & 1 \\
\hline $\mathbf{A 2}$ & & 1 & 3 & $1 / 3$ \\
\hline $\mathbf{A 3}$ & & & 1 & $1 / 5$ \\
\hline A4 & & & & 1 \\
\hline Stepen konzist. & \multicolumn{5}{|c|}{$0.016<0.1$} \\
\hline
\end{tabular}

Tabela 7. Upoređenje alterntiva u odnosu na kriterijum C4

\begin{tabular}{|c|c|c|c|c|}
\hline Alternative & A1 & A2 & A3 & A4 \\
\hline A1 & 1 & $1 / 3$ & $1 / 3$ & 1 \\
\hline $\mathbf{A 2}$ & & 1 & 1 & 3 \\
\hline $\mathbf{A 3}$ & & & 1 & 3 \\
\hline A4 & & & & 1 \\
\hline Stepen konzist. & \multicolumn{5}{|c|}{$0.00<0.1$} \\
\hline
\end{tabular}

Na kraju, nakon izvršenih proračuna dobijeni su rezultati rangiranja - tabela 8 . Rezultati pokazuju da je najbolje rešenje alternativa A3 (procesni model ISM-a).
$\mathrm{Na}$ drugom mestu je alternativa A2 (model Karapetrovića), na trećem mestu je alternativa A4 (EFQM model izvrsnosti) i na poslednjem mestu je alternativa A1 (Wilkinson - Dale-ov model).

Tabela 8. Konačni rang modela ISM-a

\begin{tabular}{|c|l|c|}
\hline Red. br. & \multicolumn{1}{|c|}{ Model ISM-a } & Rezultat \\
\hline 1. & A3 (Procesni model ISM-a) & 0.449 \\
\hline 2. & A2 (model Karapetrovića) & 0.246 \\
\hline 3. & A4 (EFQM model izvrsnosti) & 0.157 \\
\hline 4. & A1 (Wilkinson-Dale-ov model) & 0.148 \\
\hline
\end{tabular}




\section{ANALIZA DOBIJENIH REZULTATA}

Analiza obuhvata kriterijume i njihov uticaj na rangiranje modela ISM-a i same modele ISM-a.

Kada se analiziraju kriterijumi, najvažniji su njihovi težinski koeficijenti, jer je to njihova mera uticaja na rezultat rangiranja alternativa, odnosno modela ISM-a. Iz tabele 3. se vidi da kriterijum C2 (očekivani efekti ISM-a) ima najveći uticaj na rezultat rangiranja jer njegov težinski koeficijent iznosi 0,624 . To znači da on utiče sa $62,4 \%$ na donošenje odluke u odnosu na ostale kriterijume. To pokazuje da je kod izbora optimalnog modela ISM-a najvažnije šta će rudarske kompanije dobiti nakon njegove implementacije, odnosno koje će sve pozitivne efekte one ostvariti, što je i cilj ovog procesa.

$\mathrm{Na}$ drugom mestu po uticaju je kriterijum $\mathrm{C} 1$ (troškovi uvođenja ISM-a), koji utiče sa $19,3 \%$ na rezultat rangiranja. To pokazuje da su troškovi implementacije optimalnog modela ISM-a vrlo važni za rudarske kompanije, s obzirom da se one nalaze u teškoj finansijskoj situaciji.

Na trećem mestu po značaju se nalazi kriterijum C4 (primenljivost modela), koji utiče sa $13,8 \%$ na ovaj proces. To pokazuje da je za rudarske kompanije vrlo važno koliko je određeni model ISM-a pogodan za primenu u uslovima u kojima one funkcionišu. Implementacija ISM-a zahteva formiranje tima za uvođenje, sticanje novih znanja, primena novih metoda rada, upravljanja i procedura, savladavanje otpora, samo uvođenje i kontrolu dobijenih rezultata.

$\mathrm{Na}$ kraju, najmanje uticajan kriterijum je C3 (vreme implementacije ISM-a) koji ima težinski koeficijent od 0,045 . To pokazuje da je vreme koje je potrebno za uvođenje ISM-a, iako važno, u drugom planu u odnosu na ostale efekte koje se očekuju od ovog sistema.

Kod analize konačnog ranga alternativa (modela ISM-a) polazi se od optimalne (najbolje) alternative. To je alternativa A3 (procesni model ISM-a) koji ima najveći vrednost rezultata od 0,449. Razlog je u tome što se ovaj model fokusira upravo na ono što je najjača karakteristika rudarskih kompanija, a to je postojanje i neprekidno odvijanje vrlo kompleksnih i mnogobrojnih procesa u toku rada. Procesi su mesta gde se najviše može uraditi, što je i cilj ovog modela. Sa druge strane, ovaj model ISM-a integriše razne sisteme kao što su QMS, EMS, OHSAS, ali i sve zaposlene u kompanijama. Sve to omogućava značajno poboljšanje performansi rudarskih kompanija u najvećem broju ili u svim oblastima njihovog funkcionisanja.

Na drugom mestu po rangiranju se nalazi alternativa A2 (model Karapetrovića). On razmatra integraciju pet sistema - QMS, EMS, OHSAS, korporacijski menadžment sistem socijalne odgovornosti (CSRMS) i finasijski sistem menadžmenta (FMS) i okrenut je ka stalnim poboljšanjima procesa. $\mathrm{Za}$ razliku od prethodnog modela, on je složeniji, zahtevniji i manje pogodan za rudarske kompanije kod nas.

$\mathrm{Na}$ trećem mestu je alternativa A4 (EFQM model izvrsnosti), dok je na poslednjem mestu alternativa A1 (Wilkinson-Daleov model). Razlika u rezultatu između ovih modela je mala. Njihov nedostatak u odnosu na prethodna dva modela ISM-a je u tome što se oni u manjoj meri bave procesima, zatim manje su prilagođeni rudarskim kompanijama i time, manji su rezultati koji oni mogu da pruže. Dobra strana ovih modela je u tome što oni integrišu u svoj model sistem menadžmenta životnom sredinom, što je vrlo važno kod rudarskih kompanija.

\section{ZAKLJUČAK}

U ovom radu je primenjena višekriterijumska metoda donošenja odluke u cilju izbora optimalnog modela Integrisanog sistema menadžmenta (ISM) u rudarskim kompanijama u našoj zemlji. Izbor optimalnog modelaISM-a je jedna od najznačajnijih strateških odluka rudarskih kompanija. Analizirana su četiri modela ISM-a - Wilkinson-Dale-ov model (alternativa A1), model Karapetrovića (alternativa A2), procesni model (alternativa A3) i EFQM model 
izvrsnosti (alternativa A4). Takođe, razmatrana su četiri kriterijuma za rangiranje troškovi uvođenja ISM-a (kriterijum C1), očekivani efekti ISM-a (kriterijum C2), vreme implementacije ISM-a (kriterijum C3) i primenljivost modela ISM-a (kriterijum C4).

Rangiranje modela ISM-a je izvršeno pomoću AHP metode za višekriterijumsko odlučivanje. Kod ove metode, prvo se vrši određivanje težinskih koeficijenata kriterijuma za rangiranje, a onda ocenjivanje predloženih modela ISM-a i njihovo kompletno rangiranje.

Primenjena metoda za višekriterijumsku analizu može biti od velike pomoći donosiocima odluka, jer omogućava laku i kvalitetnu analizu uticajnih faktora i parametara. Na osnovu dobijenih rezultata AHP metodom, izabran je najbolji model ISM-a za rudarske kompanije u našoj zemlji, a to je procesni model (alternativa A3). Najuticajniji kriterijumiza kompletno rangiranje alternativa (modela ISM-a) su očekivani efekti ISM-a (kriterijum C2) i troškovi uvođenja ISM-a (kriterijum C1).

\section{LITERATURA}

[1] Đekić, V. et al., Importance of inter operability information and information systems in the implementation of the model IMS. Internacional Scientific Conference Managament, Mladenovac, Serbia (2012) 171-175.

[2] Heleta M., Menadžment kvaliteta, Univerzitet Singidunum, Beograd, Srbija (2008) 5.

[3] Brzaković M., Interoperabilnost i bezbednost informacija $\mathrm{u}$ organizacijama od strateškog značaja u vanrednim situacijama - Doktorska disertacija, Fakultet bezbednosti, Beograd, Srbija (2009).

[4] Volanović. S, Razvoj opšteg modela za implementaciju Integrisanog sistema menadžmenta na osnovu procene rizika u procesima organizacija, Doktorska disertacija, Fakultet Tehničkih Nauka, Novi Sad, Srbija (2014).
[5] Saaty T. L., The Analytical Hierarchy Process, New York: McGraw-Hill (1980).

[6] Bogdanović D., Obradović Lj., Miletić S.: Izbor optimalne metode sanacije degradiranih površina oko borske reke nizvodno od flotacijskog jalovišta Bor, Mining and Metallurgy Engineering Bor, 4(2014) 147-156.

[7] Wilkinson G., Dale B., Integrated management systems: a model based on total quality approach, Managing Service Quality, 11(5) (2001) 318-330.

[8] Jenkić R., Kulture i organizacije Organizacijske kulture Geerta Hofstedea, Zbornik radova Pravnog fakulteta u Splitu, 1 (2011) 103-123.

[9] https://scholar.google.com/citations? user $=$ Q2V0P6oAAAAJ\&hl=en\&oi= ao (accessed 13.05.2015)

[10] Paunkovic J., Educational Programs for Sustainable Societies Using CrossCultural Management Method. Global Sustainable Communities Handbook: Green Design Technologies and Economics (2014): 387- Butterworth Heinemann imprint of Elsevier, Elsevier Copyright (C) 2014.

[11] Paunkovic J., Zikic S., Cvetkovic A., Sustainable Utilization of Health Care Technologies is Influenced by Organizational and Cultural Factors - A Case Study. Advances in Biomedicine and Health Science, (2013) 57.

[12] Karapetrović S., Measuring of integrated management systems, Measuring Business Excellence, 7(1) (2003) 4-13.

[13] Karapetrovic S., Jonker J., Integration of standardized management systems: searching for a recipe and ingredients, Total Quality Management, 14(04) (2003) 451-459.

[14] Petrović M., Procesni pristup integrisanom menadžmentu, 33. Nacionalna konferencija o kvalitetu: Festival kvaliteta, AQS i Centar za kvalitet, Kragujevac, Srbija (2008).

[15] European Foundation for Quality Management (EFQM), EFQM Model for Business. 